\title{
BERMAIN HURUF DENGAN ELEMEN LOKAL
}

\author{
Indiria Maharsi \\ Dosen Program Studi DesainKomunikasi Visual \\ Jurusan Desain FSR ISI Yogyakarta \\ indimaharsi1@gmail.com
}

\begin{abstract}
Letters have anatomies covering subparts from which can be studied to create innovative new fonts. There are two parts of letter anatomy that can be further explored, namely the stroke and the terminal. These two are the main elements of letter anatomy.

Creating fonts incorporating local values may be initiated by referring to strokes and terminals. In order to make new typefaces, the local elements in the forms of pictures are visualized following the patterns existing in strokes and terminals. This mode of type designing is one of the easy ways to comprehend the creative process has to be underwent by a designer when he creates new letter characters.
\end{abstract}

Keywords: letter, stroke, terminal, local element

\section{PENDAHULUAN}

Berbicara masalah huruf pasti tidak bisa lepas dari tipografi. Demikian juga sebaliknya, huruf merupakan bagian utama yang dibahas dalam tipografi. Secara teori, tipografi merupakan sebuah disiplin ilmu seni yang berisi tentang pengetahuan mengenai huruf. Tipografi dikatakan sebagai seni karena dalam huruf tersebut terdapat perpaduan antara nilai fungsional sekaligus nilai estetik dari huruf tersebut (Sihombing, 2001: 3). Selain itu, tipografi didefinisikan sebagai sebuah kajian, penggunaan, dan desain seperangkat bentuk-bentuk huruf terulang yang identik atau sama (Robinovitz, 2006: 1). Dengan demikian nilai fungsional dan estetika menjadi hal penting dalam dunia huruf atau lebih luas lagi dunia tipografi.
Selain itu berbicara masalah huruf bisa berarti berbicara tentang tiga hal yaitu kajian yang bersifat membedah huruf secara teoritis, mendesain atau merancang huruf dan yang terakhir penggunaan dari huruf tersebut.

Namun pada intinya sebetulnya bisa dikatakan bahwa tipografi adalah seni tentang mendesain, mencipta, memilih dan memilah, menata dan mengorganisir huruf dalam segala aspek ketentuan yang meliputi dirinya dan berkaitan erat dengan estetika serta komunikasi yang efektif karena mampu mewakili konsep dan inti pesan yang disampaikan melalui karakter serta ciri khas huruf yang dimilikinya (Maharsi, 2013: 10). Pada intinya juga bisa dikatakan bahwa tipografi itu adalah studi dan seni penggunaan huruf (Lukman, 2015: 111). Dari 
sini jelas sekali bahwa titik utama yang dibahas dalam tipografi adalah huruf dalam segala aspeknya.

Jika dilihat secara seksama, huruf memiliki unsur pembentuk yang berupa garis lurus dan garis lengkung dengan ketebalan yang berbeda-beda. Garis-garis yang berbagai macam tersebutlah yang sebetulnya membentuk sebuah huruf. Sehingga bisa dikatakan bahwa sebetulnya material dasar dari huruf atau aksara adalah garis. Garis menjadi dasar pembentuk dari huruf, utamanya huruf Latin yang dipakai saat ini secara luas. Lewat garis-garis tersebutlah proses reka cipta kreator huruf tervisual dalam bentuk-bentuk yang berbeda satu sama lain, menambah dan mengurangi satu sama lain. Atau bahkan berkolaborasi membentuk sesuatu yang unik dan menarik serta tentu saja inovatif. Lahan garap dalam huruf yang sedemikian luas karena materialnya yang begitu sederhana (garis) menjadikannya pada saat ini jumlah huruf sedemikian banyak tidak terhitung. Terlebih lagi perkembangan tekhnologi memudahkan seseorang untuk membuat atau berkreasi mencipta huruf dengan software-software pembuat huruf yang sedemikian melimpah di dunia maya.

Dalam bahasa yang lain, huruf memiliki anatomi yang terdiri dari beberapa bagian. Beberapa bagian yang ada tersebut mewakili tempat maupun bentuk uniknya. Sebut saja Tails yang posisinya berada dibawah seperti layaknya ekor yang terdapat pada badan hewan. Tails dalam anatomi huruf terdapat pada huruf 'Q'. Selain Tails, dalam huruf Latin secara anatomi terdapat pula Arm, Legs, Shoulders, dan lain-lain. Setiap bagian dari anatomi tubuh huruf tadi bisa dieksplorasi beberapa bagian darinya, atau bisa juga seluruhnya. Namun sebetulnya ada dua bagian dalam anatomi huruf yang bisa dijadikan pedoman dasar untuk membentuk karakter-karakter huruf yang ada, dua bagian dalam anatomi huruf tersebut adalah Strokes dan Terminal.

Yang dimaksud dengan Strokes adalah setiap garis yang dipakai untuk membentuk sebuah huruf. Strokes bisa berbentuk lurus ataupun melengkung. Bisa tebal maupun tipis. Jika bentuk dari Strokes tersebut lurus maka disebut sebagai Stem Strokes yang umumnya lebih tebal. Namun jika Strokes tersebut lebih tipis disebut sebagai Hairline Strokes (Maharsi; 2002: 50). Selain Strokes terdapat pula bagian-bagian yang disebut sebagai Cross Stroke, Crossbar, Spine, Arm, Leg, Tail, dan Bowl. Dalam huruf script terdapat tambahan yang menarik, Strokes bisa diperpanjang dan bersifat dekoratif yang kadang mengarah dari Terminal. Bentuk yang seperti itu disebut sebagai Swash. 


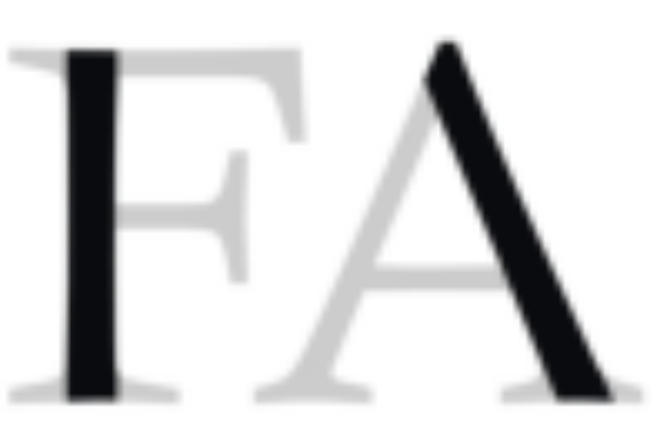

Gambar 1 Stem Strokes

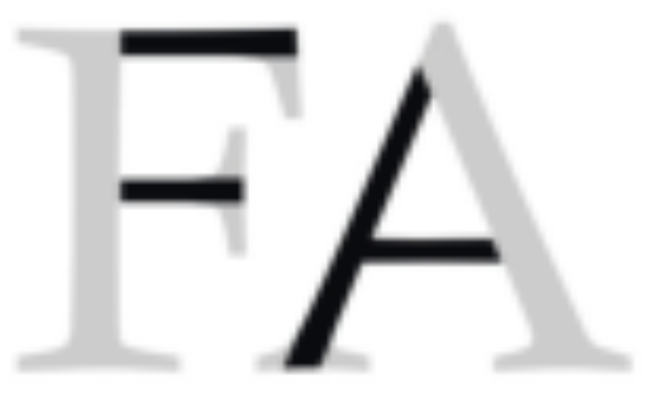

Gambar 2 Hairline Strokes.

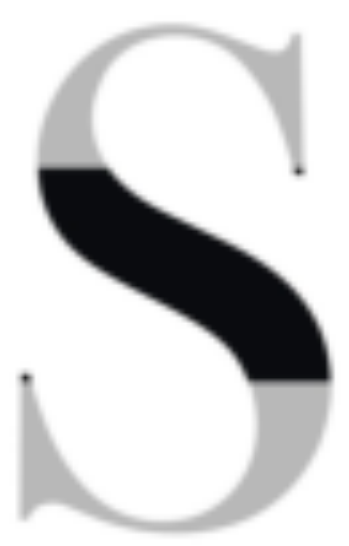

Gambar 3 Spine

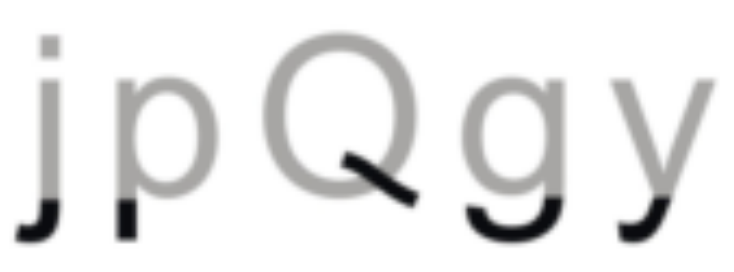

Gambar 4 Tails

Sedangkan yang dimaksud dengan Terminal adalah titik ujung dari sebuah Strokes. Strokes memiliki ujung yang berbeda dan bervariasi pada bentuknya. Ketika ujung tersebut memiliki perpanjangan pada terminalnya maka disebut sebagai serif, namun jika tidak maka disebut sebagai san serif atau tanpa serif (Maharsi, 2002: 57). Kata 'Sans' dalam Bahasa Perancis berarti 'tanpa', jadi Sans-serif berarti tanpa Serif. Penggunaan Serif pada terminal huruf dianggap sebagai warisan dari Romawi Kuno. Hal ini karena alat yang digunakan untuk mengukirkan huruf di dinding-dinding maupun tablet-tablet meninggalkan perpanjangan semacam itu pada Terminal hurufnya. Oleh karena itu, huruf-huruf tegak bukan italic yang memiliki Serif sering disebut huruf Roman.

Terdapat sembilan bentuk Terminal dalam anatomi huruf, yaitu; Horisontal, Vertical, Rounded, Cupped, Sheared, Oblique, Teardrop Shaped, Ball Shaped, dan Pointed. Bagian-bagian tersebut memiliki bentuk dengan cirinya masing-masing. Dan pada 
dasarnya bagian anatomi huruf Strokes dan Terminal itulah letak eksplorasi bisa dilakukan. Utamanya ketika melakukan dekonstruksi huruf, ataupun mencoba menggabungkan antara huruf Latin dengan elemen visual lain sebagai upaya penggabungan antara huruf dengan gambar. Upaya ini sebetulnya sangat penting dilakukan dalam rangka bermain dengan huruf tadi. Kebebasan dalam menuangkan gagasan didahului dengan pemahaman anatomi huruf menjadi modal penting dalam proses kreatif tersebut.

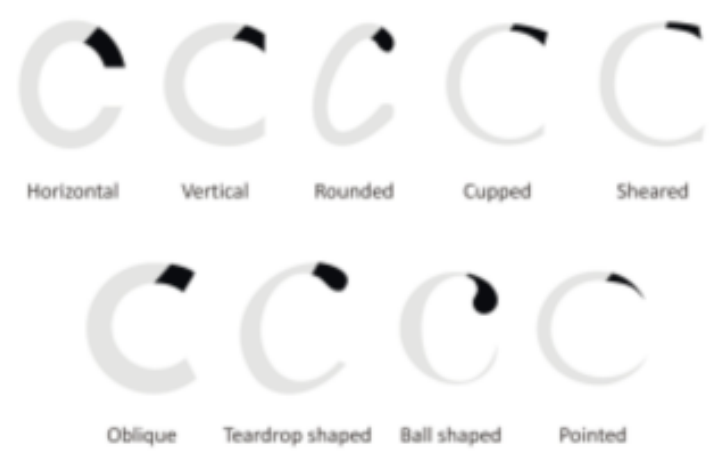

Gambar 5 Terminal

\section{MERANCANG HURUF LATIN DENGAN ELEMEN LOKAL}

Membentuk huruf Latin dalam model apapun memang kelihatannya mudah, namun sebetulnya membutuhkan proses yang panjang dan jeli untuk menjamin bahwa karya yang tercipta nantinya memiliki muatan estetis yang mencerminkan konsepsi yang jelas dari bentuk visual yang dibentuknya. Karya seni dalam bentuk huruf ini membutuhkan pula kepekaan dari seorang desainer tipografi untuk mampu secara tepat dan pas merancang sebuah karya yang berupa huruf yang mudah dibaca serta memiliki kemampuan 'berkomunikasi' secara tidak langsung kepada audiens lewat pesan dalam bentuk visual huruf itu. Pesan tersebut akan tersampaikan lewat kesan yang diterima oleh audiens, seperti kesan seram, lucu, komikal, futuristik, klasik dan lain-lain.

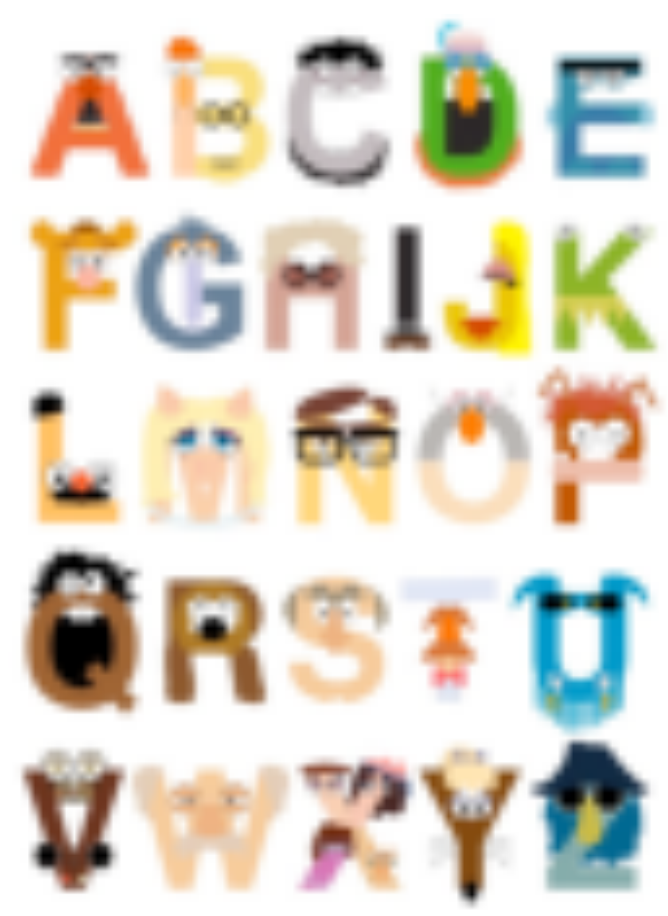

Gambar 6 Huruf lucu untuk anak-anak

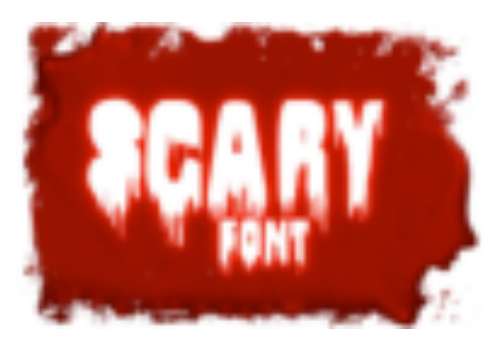

Gambar 7 Contoh huruf berkesan seram 


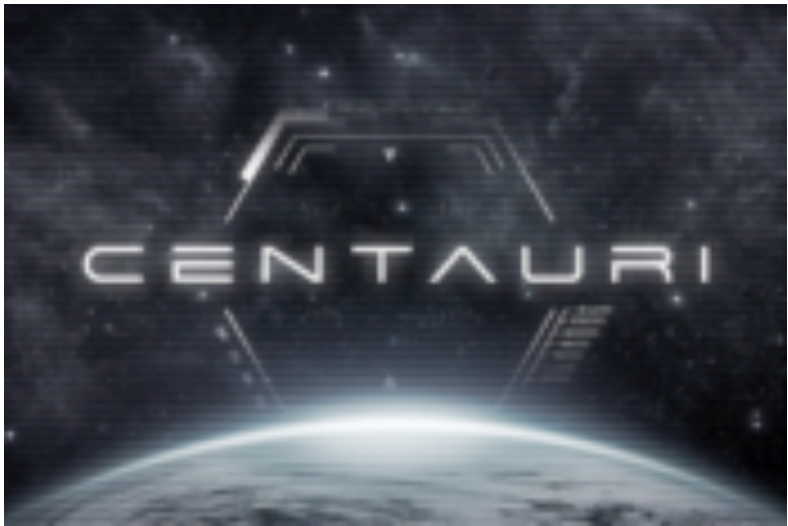

Gambar 8 Contoh huruf yang futuristik

Berkaitan dengan hal itu, merancang sebuah huruf dengan elemen visual yang merujuk pada lokalitas menjadi penting mengingat begitu banyaknya materi yang bisa didapat dalam ranah lokal tersebut. Kelokalan dalam bahasan ini adalah karya budaya yang ada di Indonesia yang begitu beragam. Bisa berupa benda budaya, ritual budaya, ataupun yang lain. Bisa jadi pula kelokalan merujuk kepada setiap elemen yang ada di tanah Indonesia baik flora, fauna maupun keragaman suku yang ada didalamnya. Merancang huruf seperti ini sebetulnya analoginya sama seperti bermain dengan huruf. Konteks bermain berarti bebas mencari ide model apapun untuk diterapkan dalam huruf. Dekonstruksi yang dilakukan terhadap huruf Latin dan unsur apa yang dimasukkan dalam huruf Latin tersebut menjadi hak sepenuhnya seorang kreator huruf atau tipografer. Dan jika proses kreatif tersebut dilakukan dengan menggali ide dari lokalitas Indonesia ini maka bahan dasar untuk membuat huruf tidak akan habis mengingat Indonesia memiliki jutaan hal yang bisa dijadikan sebagai sumber ide. Entah itu budayanya, legenda, mitos, kuliner, flora dan fauna ataupun yang lain. Semua menarik untuk dijadikan sebagai sumber ide. Contoh dari bermain huruf seperti yang terlihat pada beberapa karya berikut ini.

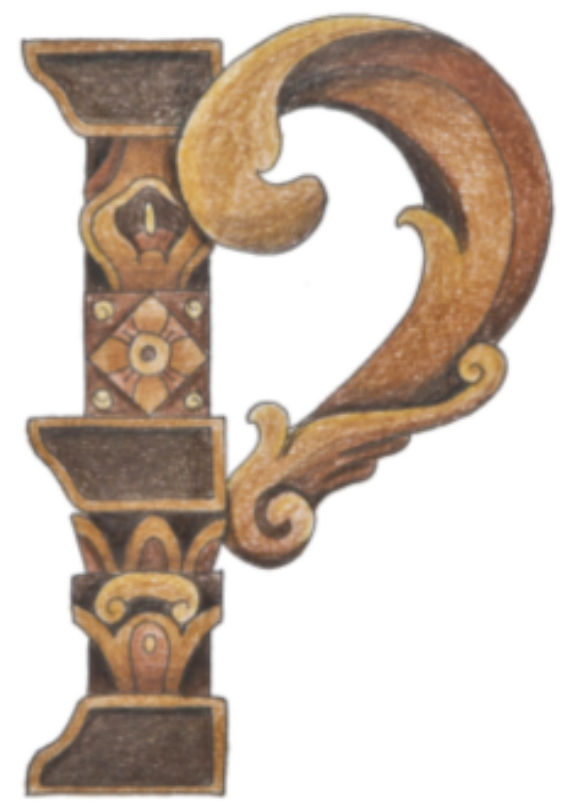

Gambar 9 Huruf 'P'

Seperti yang terlihat pada huruf ' $\mathrm{P}$ ' diatas, karya tersebut mengesplorasi uniknya ukuran-ukiran yang ada pada ukiran Jepara. Ukiran Jepara yang penuh dengan lengkunglengkung dan bidang tegak vertikal tersebut dijadikan materi sebagai bahan membuat huruf yang unik dan inovatif. 

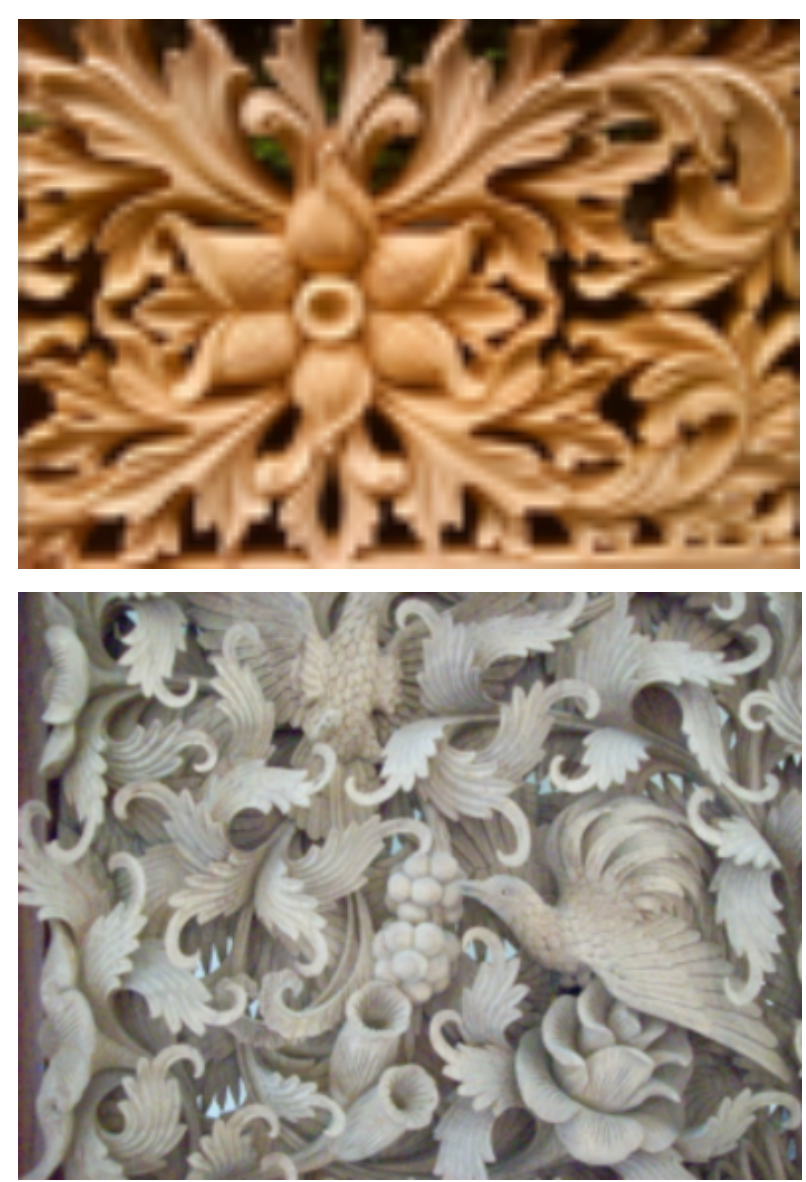

Gambar 10 Ukiran Jepara

Beda lagi dengan karya-karya dibawah ini yang mengeksplorasi keragaman kekayaan fauna yang ada di Indonesia. Keragaman fauna tersebut diambil beberapa yang menarik dan dijadikan sebagai bahan atau materi membuat huruf. Tingkat kesulitan dalam membuat karya ini adalah bagaimana bentuk hewan yang hidup itu bisa ter-display dengan menarik. Beberapa diantaranya tetap menambahkan elemen pendukung lain seperti pohon, bunga atau tanaman sebagai bagian yang tidak terpisah dari kehidupan hewan itu sendiri.

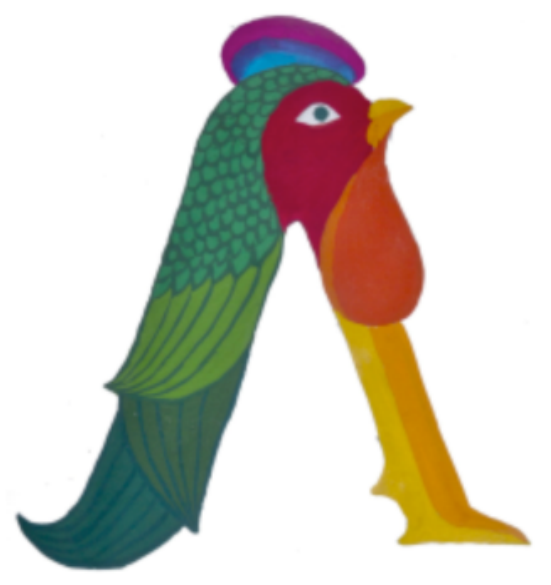

Gambar 11 Huruf 'A' dengan mengeksplorasi kekayaan fauna nusantara

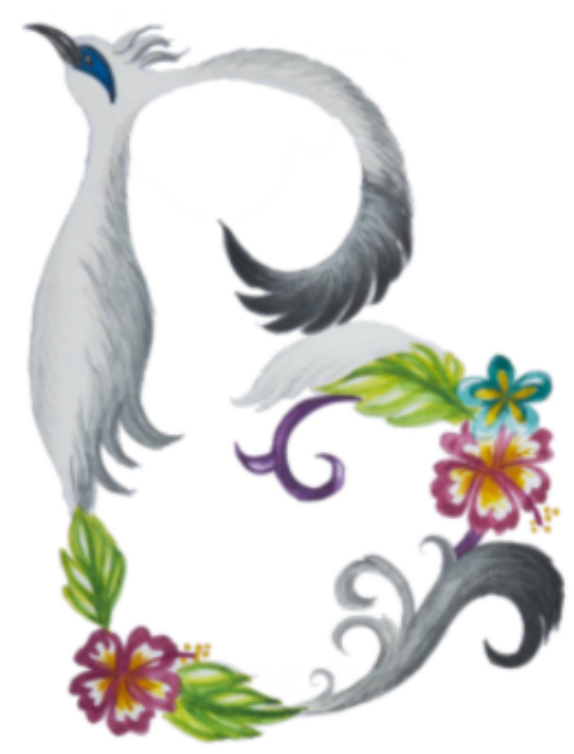

Gambar 12 Huruf 'B' dengan mengeksplorasi kekayaan fauna nusantara 


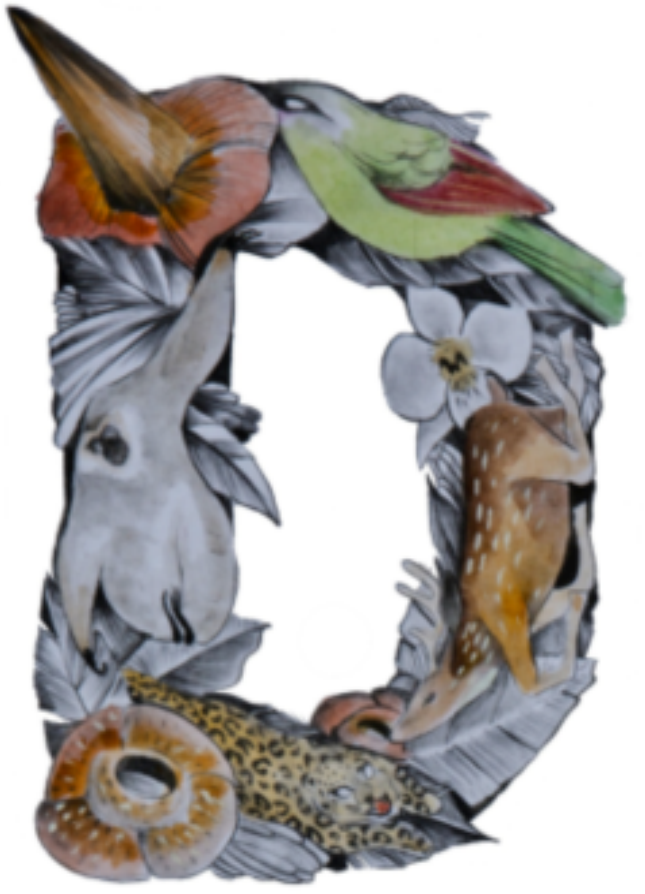

Gambar 13 Huruf 'D' dengan mengeksplorasi kekayaan fauna nusantara

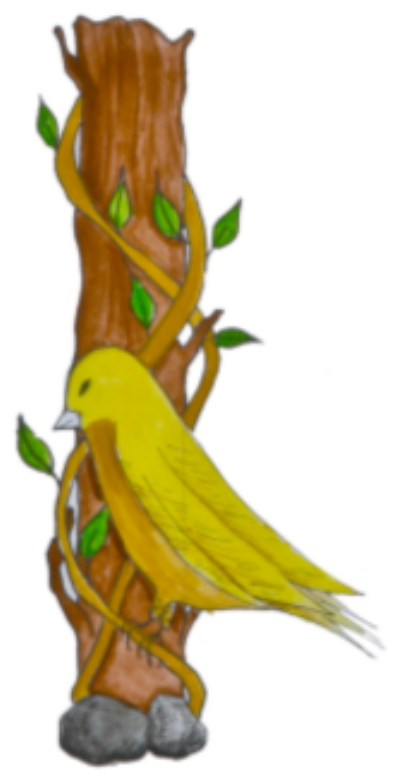

Gambar 14 Huruf 'I' dengan mengeksplorasi kekayaan fauna nusantara

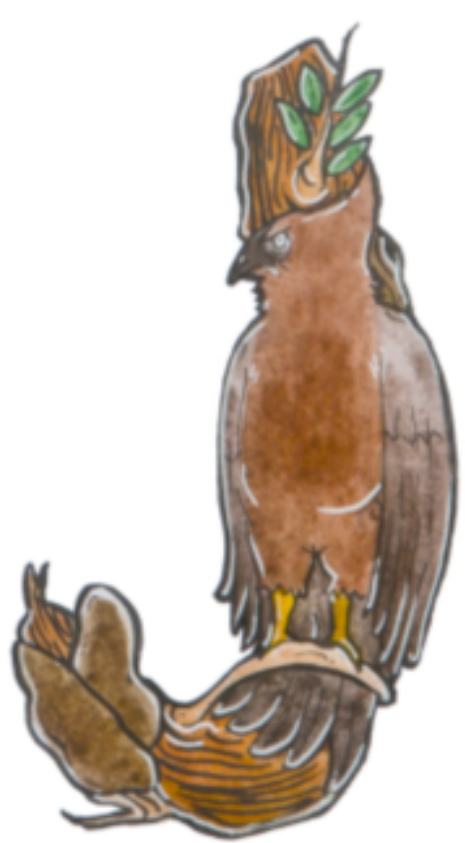

Gambar 15 Huruf 'J' dengan mengeksplorasi kekayaan fauna nusantara

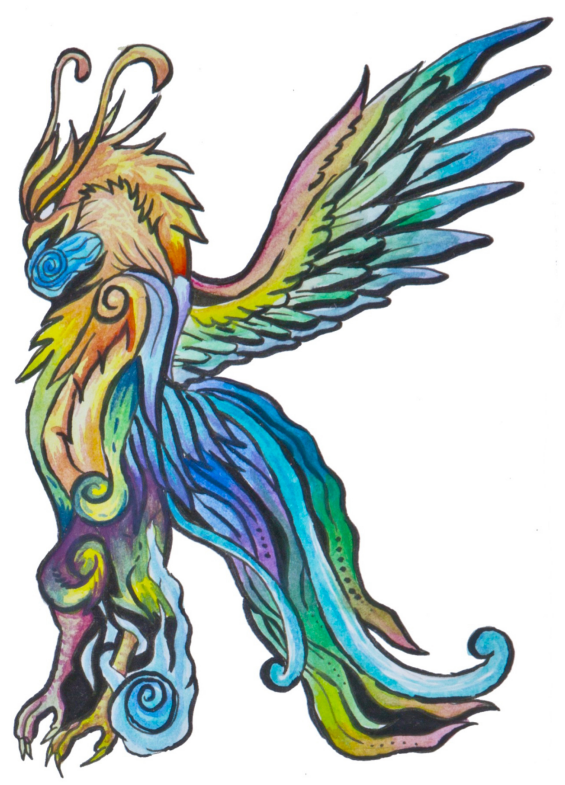

Gambar 16 Huruf 'K' dengan mengeksplorasi kekayaan fauna nusantara

Selain fauna, bisa juga keragaman kuliner dijadikan sebagai bahan atau materi eksplorasi. Begitu banyak dunia kuliner di 
Indonesia, mulai dari soto dengan gerobaknya, dawet, kerak telur, dan lain sebagainya. Sebagai contoh salah satu karya dibawah ini yang memakai salah satu budaya kuliner yang marak terdapat di Yogyakarta yaitu angkringan. Angkringan sendiri berasal dari bahasa Jawa 'Angkring' yang artinya adalah alat dan tempat jualan makanan keliling yang pikulannya berbentuk melengkung kearah atas. Angkringan bisa dianrtikan sebagai sebuah gerobag dorong yang menjual berbagai macam makanan dan minuman yang biasa terdapat di setiap pinggir ruas jalan di Yogyakarta dan Jawa Tengah.

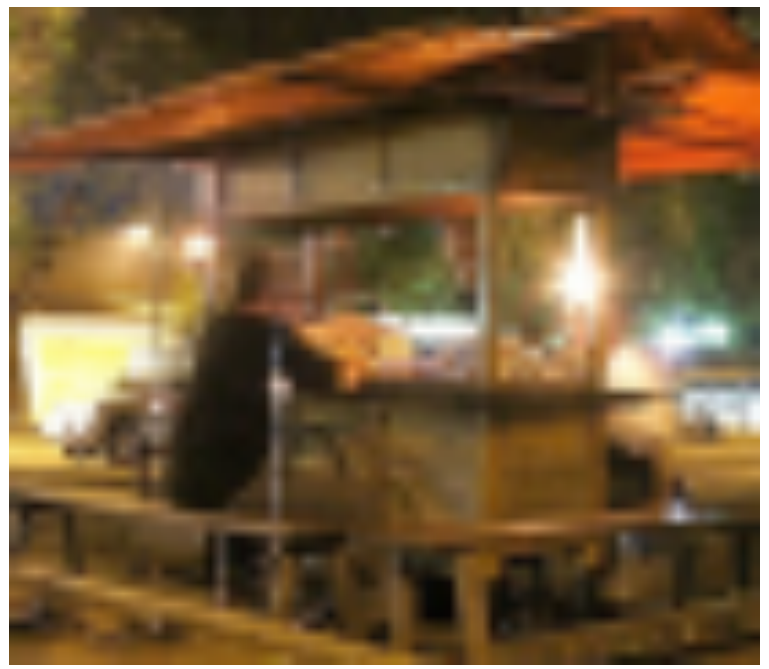

Gambar 17 Gerobak angkringan

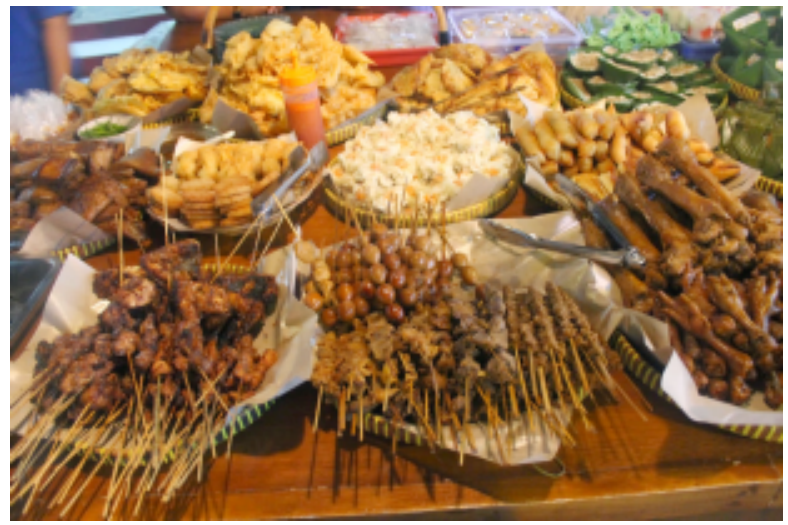

Gambar 18 Menu jajanan di angkringan

Biasanya angkringan diberi tutup terpal plastik atasnya dan memuat sekitar minimal lima orang yang duduk di bangku yang panjang. Wedang jahe, susu, kopi dan the panas merupakan menu minum wajib di tempat angkringan ini. Jajanan khas yang dijual di angkringan seperti sate telur puyuh, tempe goring, sate usus, tahu goreng, nasi kucing dengan lauk teri dipakai sebagai bahan membuat huruf. Jajanan yang ada di warung angkringan tersebut dijadikan sebagai bahan membuat huruf hasilnya sungguh menarik. Bukan hanya mampu menampilkan huruf ' $\mathrm{E}$ ' secara beda namun juga menyampaikan atau mewartakan tentang kuliner angkringan yang cukup popular di kota Yogyakarta. 


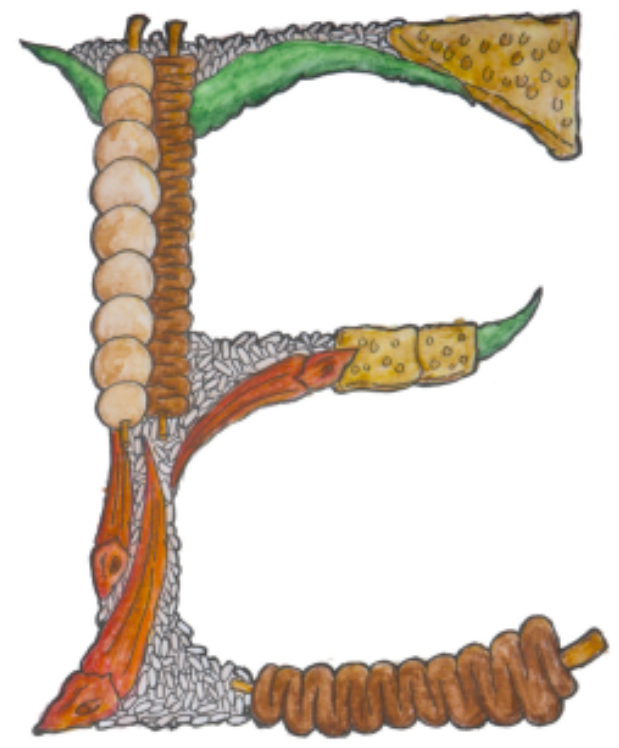

Gambar 19 Huruf 'E' dengan mengeksplorasi jajanan angkringan

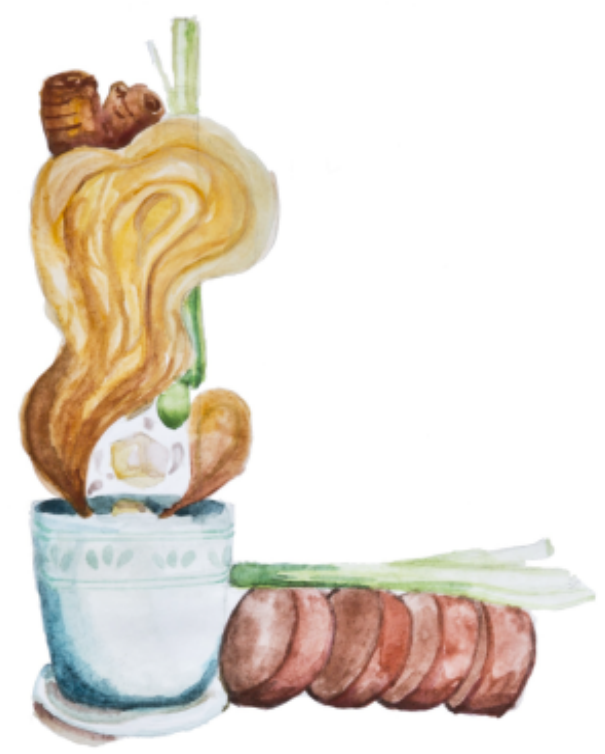

Gambar 20 Huruf 'L' dengan tema kuliner

Selain kuliner maupun fauna, masih ada lagi yang bisa dijadikan sebagai bahan untuk bermain dengan huruf Latin, salah satunya adalah cerita rakyat atau folklore. Banyak sekali cerita rakyat yang ada di Indonesia, cerita-cerita tersebut hadir dalam bentuk mitos, legenda, dongeng dan lain sebagainya. Sebagai contoh legenda Ratu Pantai Selatan, dongeng Malin Kundang, cerita Wayang, legenda Sangkuriang, dongeng Keong Emas, dan lain-lain. Jalan cerita dari naskah tersebut bisa dijadikan sebagai bahan untuk membuat huruf. Visualisasi dari huruf tersebut bisa mengikuti alur atau plot dari naskah cerita tersebut atau hanya menampilkan karakter tokohnya saja.

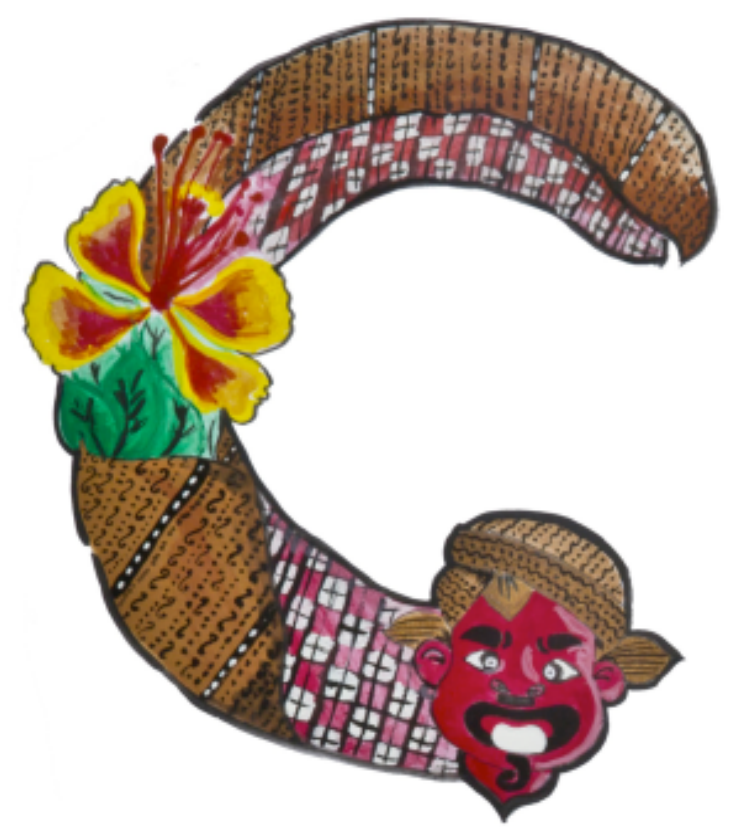

Gambar 21 Huruf 'C' dengan tema cerita rakyat Gambar 22 


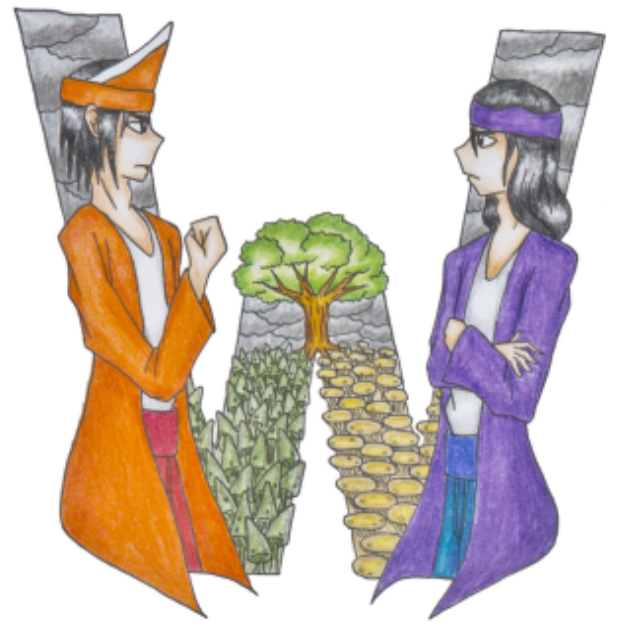

Gambar 23 Huruf 'W' dengan tema cerita rakyat

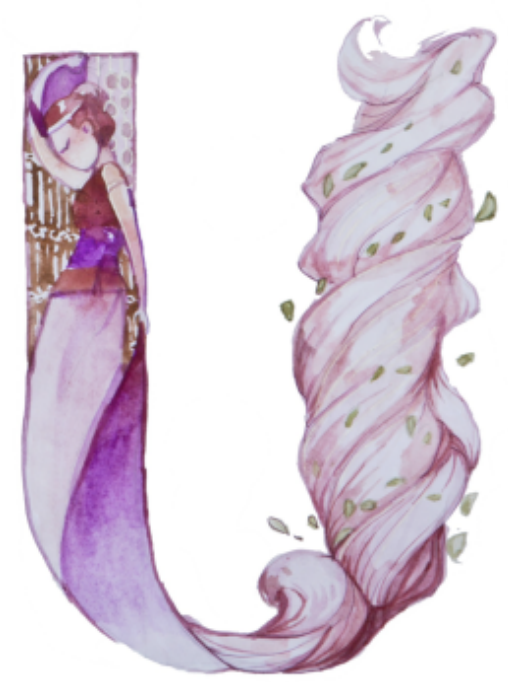

Gambar 24 Huruf 'U' dengan tema cerita rakyat

Yang dicontohkan diatas sebetulnya hanyalah sebagian kecil dari materi atau bahan apa yang bisa dieksplorasi berkaitan dengan perancangan huruf. Masih banyak kekayaan nusantara ini yang bisa digali. Dan mungkin tidak akan habis, mengingat begitu banyak ragam suku dan budaya yang dimilikinya. Keragaman itu menjadi bahan yang sangat potensial untuk dikaji, diteliti dan dijadikan sebagai meteri utama perancangan sebuah huruf atau serangkaian huruf, karena bermain dengan huruf bukan hanya membuat bagaimana huruf itu menjadi menarik namun juga memberikan nilai yang beda dari huruf yang tercipta.

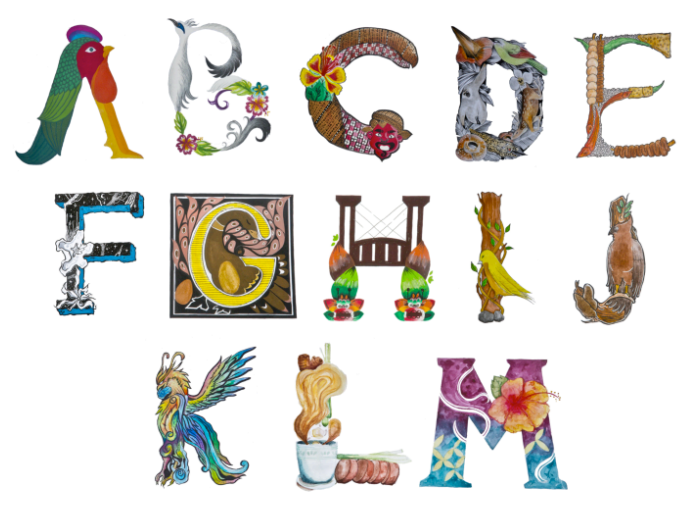

Gambar 25 Perancangan huruf dengan tema budaya nusantara dari 'A' sampai 'M'
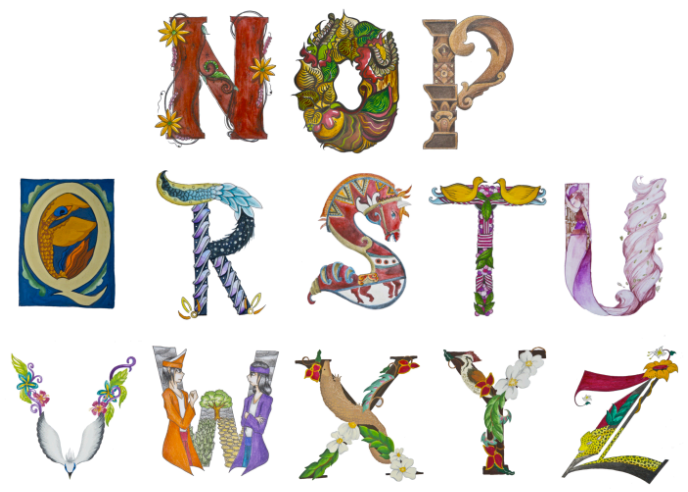

Gambar 26 Perancangan huruf dengan tema budaya nusantara dari 'N' sampai ' $Z$ '

Melihat karya-karya diatas maka bisa dikatakan bahwa elemen-elemen lokal yang hadir ditempatkan dalam bagian Strokes dan 
Terminal. Keduanya diisi oleh elemen-elemen lokal yang dipilih dan ditempatkan pada bagian yang tepat dan memenuhi kaidah estetis. Penempatan elemen-elemen lokal tersebut tidak bisa dilakukan dengan sembarangan mengingat bahwa karakter dari Strokes dan Terminal dalam setiap huruf itu berbeda-beda. Sehingga membutuhkan kejelian dalam 'membaca' karakter huruf dan karakter serta bentuk dari elemen lokalnya.

\section{KESIMPULAN}

Strokes dan Terminal merupakan bagian dari anatomi huruf yang bisa dieksplorasi menjadi bentuk-bentuk yang beraneka ragam. Kedua bagian dari anatomi huruf itulah sebetulnya yang merupakan inti dari pembentuk huruf Latin. Sehingga membuat atau merancang huruf yang baru memerlukan pemahaman dan kejelian dalam melihat bentuk dan model Strokes serta Terminal pada masing-masing karakter huruf dari A-Z. Karena karakter dan bentuk huruf dari A sampai $\mathrm{Z}$ sangat berbeda-beda.

Elemen-elemen lokal yang merujuk kepada keragaman budaya bangsa Indonesia bisa dijadikan sebagai bahan untuk membuat huruf. Elemen-elemen lokal tersebut bisa ditempatkan dalam bagian-bagian Strokes serta Terminal dengan memperhatikan ketepatan dan estetika bentuk yang kolaboratif antara keduanya. Kejelian dan rasa estetis sebetulnya menjadi hal yang perlu diperhatikan dalam proses perancangan tersebut. Hal ini karena masing-masing elemen lokal itu berbeda-beda dan bagaimana elemen-elemen tersebut bisa secara pas menempati posisi pada Strokes maupun Terminal. Hal lain yang juga perlu menjadi perhatian adalah bahwa setiap bagian dari elemen lokal perlu dipilih secara cermat, utamanya yang bisa mewakili pesan dari kelokalan tersebut.

$$
\text { Sehingga dengan demikian }
$$
perancangan huruf dengan sumber ide elemen lokal dengan memanfaatkan Strokes dan Terminal menjadi sesuatu yang bisa memberi bentuk baru dalam dunia penciptaan huruf. Disamping itu kekhasan yang muncul dari terciptanya huruf dengan nuansa lokal itu memberikan gairah baru untuk lebih mengamati sekaligus mengeksplorasi materi-materi lokal yang ada disekitar kita. Bahwa begitu banyaknya materi tersebut dan begitu kayanya model serta karakter yang bisa didapat dan diterapkan sebagai sumber ide bagi perancangan sekaligus penciptaan huruf-huruf baru dalam dunia tipografi di Indonesia.

\section{DAFTAR PUSTAKA}

[1] Maharsi, Indiria. (2013), Tipografi Tiap Font Mewakili Nyawa dan Arti, Penerbit CAPS, Yogyakarta. 
[2] Purnama Lukman, Nikko. (2015), Kamus Visual Tipografi, Penerbit DGI Press, Jakarta, 2015.

[3] Robinovitz, Tova. (2006), Exploring Typography, Thomson/Delmar Learning, USA.

[4] Sihombing, Danton. (2001), Tipgrafi Dalam Desain Grafis, Penerbit PT Gramedia Pustaka Utama, Jakarta. 